\title{
The Future of Wild Mammals in Oil Palm Landscapes in the Neotropics
}

\author{
Esteban Payán* and Valeria Boron \\ Panthera, New York, NY, United States
}

We assume conservation lessons learnt from Southeast Asia adapted to the growing body of knowledge in oil palm impacts in Colombia, and adapt it to the Neotropical realm with a focus on mammals. Aspects of science, policy, and practice are reviewed. Colombia is the fourth largest producer of palm oil in the world with a growth of $42 \%$ in 2017, affecting its ecosystems and biodiversity. In order to prevent large mammal species erosion and decimation as has happened in SE Asia, the following lessons in zoning, infrastructure, harvest, monitoring, and research should be implemented. Native habitat is irreplaceable. New oil palm frontiers should occur in degraded ecosystems, with adequate governance and without requirement of new infrastructure. Roads favor hunting, logging, and disorganized human occupation. Plantations should conserve water bodies and forests to ensure connectivity and refuge for sensitive mammal species. Higher structural complexity with added plants is desired for a varied mammal species

OPEN ACCESS

Edited by:

Katharine Anne Abernethy, University of Stirling, United Kingdom

Reviewed by:

Badrul Azhar,

Putra Malaysia University, Malaysia Andres Etter, Pontifical Javeriana University, Colombia

*Correspondence: Esteban Payán epayan@panthera.org

Specialty section: This article was submitted to Tropical Forests, a section of the journal Frontiers in Forests and Global

Change

Received: 27 April 2019 Accepted: 16 September 2019 Published: 11 October 2019

Citation:

Payán E and Boron V (2019) The

Future of Wild Mammals in Oil Palm Landscapes in the Neotropics. Front. For. Glob. Change 2:61. doi: 10.3389/ffgc.2019.00061 composition. Harvest should be done manually and crepuscular work hours should be avoided. How new oil palm frontiers are opened and developed will define the extent of alteration of natural mammal assemblages, the intensity of mesopredator release affecting other species from cascading trophic phenomenon and even the continuation of key large iconic herbivores and carnivores.

Keywords: agriculture, Panthera onca, Colombia, pastures, sustainability, mesopredators, vertebrates, Panthera tigris

\section{INTRODUCTION}

Agricultural expansion, including oil palm, is driving severe habitat loss and degradation, threatening biodiversity worldwide (Balmford et al., 2012; Vijay et al., 2016). This is particularly concerning for the equatorial countries given their extremely rich in biodiversity and the unprecedented land cover change (Laurance et al., 2014). Latin America is poised to be the second largest oil palm producing region in the world after Southeast Asia (SE Asia) (Furumo and Aide, 2017). Colombia is the 4th largest palm oil producer in the world, followed closely by Honduras, Perú, and Guatemala, with growing productions from Ecuador and Brazil.

Forest and other well-conserved ecosystems falling to oil palm conversion are a critical threat to mammal conservation. This has been evidenced in SE Asia with the local extinctions, mammal assemblage alterations, and dwindling population of large mammals (Clements et al., 2010; Wilcove et al., 2013). Mammals make significant contributions to ecosystem functioning including trophic regulation, nutrient cycling, carbon storage, seed dispersal, and ultimately maintenance of forest (Terborgh and Estes, 2013). Amongst mammals, large-bodied ones play a focal species role and are especially vulnerable to habitat loss (Ripple et al., 2014). Mammals are ideal as a proxy for sustainability since they have some of the highest extinction risk predictor among taxa, especially from human activity, as has been evidenced through history, and as terrestrial dwellers are strongly 
impacted by oil palm plantation and easily monitored with camera traps (Cardillo et al., 2005; Fitzherbert et al., 2008; Koh and Wilcove, 2008).

We assume conservation lessons learnt from SE Asia adapted to the growing body of knowledge in oil palm impacts in Colombia, and adapt it to the Neotropical realm with a focus on mammals. Here we synthesize these in a perspective piece to infer ways to minimize impact in the expected increase of oil palm in the Neotropics and achieve more sustainable agricultural landscapes.

\section{LANDSCAPE ZONING TO LESSEN THE IMPACT OF OIL PALM}

In Southeast Asia and South America, 45 and 31\%, respectively, of sampled oil palm plantations came from areas that were forests in 1989 (Vijay et al., 2016). Indonesia lost 70\% of its lowland forests (1990-2005) to deforestation, largely led by establishment of oil palm plantations (Carlson et al., 2013). Southeast Asia had $6 \%(\sim 880,000 \mathrm{ha})$ of tropical peatland converted to oil palm by 2005 , with an estimated species loss of $\sim 12 \%$ (Koh et al., 2011). Oil palm production is rapidly expanding in Latin America (Furumo and Aide, 2017) and ensuring that this expansion is not met at the expense of tropical forest habitat and mammal biodiversity should represent a regional conservation priority. Based on a sample of 342,032 ha of oil palm plantations across Latin America, Furumo and Aide (2017), found that $79 \%$ replaced previously intervened lands, which is ideal, but the remaining $21 \%$ came from deforestation, most notably in the Amazon and the Petén region in northern Guatemala. In Colombia, of the 155,100 ha of new oil palm plantations between 2002 and 2008, 16.1\% occurred in forests and natural savannas (Castiblanco et al., 2013). In the Peruvian Amazon, GutiérrezVélez et al. (2011) assessed the area deforested by industrial-scale high-yield oil palm expansion between 2000 and 2010, finding that $72 \%$ of new plantations expanded into forested areas. New oil palm frontiers should occur in degraded ecosystems, with adequate soils, local governance and without the requirement of new infrastructure. Road creation and upgrading is a catalyst for both habitat loss and overhunting, two major drivers of mammal extinction. Roads bring access to loggers, hunters, poachers, and general human occupation directly decimating mammal population, creating avoidance gaps, and fragmenting and eroding their habitats (Laurance et al., 2014). Unpaved roads are more wildlife-friendly than paved ones, and a more sustainable option for the oil palm sector, since the product is not perishable.

Many areas with climatic suitability for oil palm in the Neotropics retain extensive cover of primary forests, and therefore have major conservation value (Butler and Laurance, 2009). The Neotropics have enough over grazed and poorly farmed lands to spare for oil palm cultivation (Wassenaar et al., 2007; Garcia-Ulloa et al., 2012). Also, research demonstrated that pastures have low conservation value for several taxa in Colombia (Gilroy et al., 2015; Boron et al., 2019), and conversion to oil palm plantations could, in theory, improve this for generalist mesopredator species like ocelots (Leopardus pardalis) (see below). However, intensifying use of the land will lessen the impact of agriculture on natural ecosystems only if coupled with effective land-use planning at all scales of development (Laurance et al., 2014). This, however, is not the current case. Governments see the social and economic benefits of oil palm expansions, and benefit the sector with subsidies and incentives (Rist et al., 2010; Boron et al., 2016). This is aggravated by poor land governance, deficient enforcement, weak institutions, and corruption (Boron et al., 2016). Both stronger regulatory frameworks and incentivebased approaches could facilitate land-use planning and help preserve natural areas.

\section{NATIVE FOREST IS IRREPLACEABLE}

Native forest biodiversity is not as high in selective logged forest, secondary forest, oil palm, or natural savannas (Gibson et al., 2011). Conversion of forest to oil palm plantations causes irreplaceable biodiversity loss (Wilcove et al., 2013). Large mammalian herbivores and carnivores depend on intact forest for reproduction and long-term survival.

Studies in Asia have revealed severe declines in abundance and species richness in oil palm relative to forests (Edwards et al., 2010; Yue et al., 2015). In Colombia, mammal richness was significantly lower $(-47 \%)$ in oil palm areas when compared to adjecent riparian forest and when oil palm cover reaches $45-$ $75 \%$, mammal species composition drastically changes (Pardo and Payán, 2015; Pardo et al., 2018a,b). Research also showed that forest areas and wetlands increase occupancy, relative abundance, and are key core areas for jaguars (Panthera onca), pumas (Puma concolor), ocelots, jaguarundis (Herpailurus yagouaroundi), other mesopredators, and medium rodents (Diaz-Pulido and Payán, 2011; Boron and Payán, 2013; Boron et al., 2018). These species will use the oil palm agro habitat only marginally. These findings suggest that maintaining forest and wetland habitat in modified landscapes is crucial for both the wild felid guild and their prey.

These examples show how irreplaceable native forest is in comparison to oil palm of multiple ages. In light of rapidly expanding agriculture across the Neotropics, these findings can inform land use planning and conservation policies in Latin America.

\section{MANAGEMENT OF OIL PALM PLANTATIONS}

Mammals are wide ranging; hence, their conservation should be done at landscape-wide scale and involve land use planning and forest conservation inside and outside plantations. Here, oil palm plantation best practices have a key role.

The following landscape variables in Colombia define a great deal of the sustainability of oil palm plantations for mammals: the size of plantations, distance to well-conserved forest patches or mosaic of plantations with forests. This agrees with research in Southeast Asia where small plantations are viable refuges for small and medium mammals, where small plantations close 
to well-conserved forest will sustain richer biodiversity (Azhar et al., 2014, 2015). Large mammals such as tiger (Panthera tigris) (Sunarto et al., 2012), sun bears (Helarctos malayanus), or orangutans (Pongo spp.) disperse into mature plantations and will use them as long as they are close to well-conserved forest (Ancrenaz et al., 2015). Sunarto and colleagues highlight that with adjustments in plantation management, tigers could use mosaics of plantations (as additional roaming zones), riparian forests (as corridors), and smaller forest patches (as stepping stones), potentially maintaining a metapopulation structure in fragmented landscapes. In the Colombian llanos when oil palm cover increased to $75 \%$ or more, almost the entire terrestrial mammal community declined abruptly (Pardo et al., 2018b).

As with any crop, oil palm should not be planted homogeneously over entire landscapes, but rather within mosaic landscapes together with well-conserved native habitats. Plantation design should maintain appropriate native vegetation buffer zones between plantations, respecting patches and riparian corridors, distances from plots to riverbeds, conserve existing water bodies, and implement drop or localized irrigation to ensure connectivity and refuge for sensitive mammal species. Proximity to water significantly increased Neotropical mammal community occupancy in Colombia (Boron et al., 2019). Positive associations of mammals with water likely reflect the use of riparian forests for movement and dispersal as these forests tend to be the only ones to remain in modified landscapes.

Plantations with more complex understory and general heterogeneous structures are richer in mammals as seen in SE Asia and in Colombia (Azhar et al., 2015; Pardo and Payán, 2015; Pardo et al., 2018a). This might also protect the oil palms from insectivory (Koh, 2008) and presumably other disease and pests. Harvest should be done manually to maximize employment and minimize machinery. Crepuscular and night-time work hours should be avoided so that mammals may adapt to circadian activity rhythms with minimum disturbance and noise. Human disturbance not only alters natural mammal activity patterns, but can also increase competition due to this alteration (Bennie et al., 2014). Drainage canals should have crossing structures for land animals and low angle borders for water dwelling ones. Stakeholders should ensure zero hunting, low speed on roads and no burning.

Many of the above recommendations and others are included in the Roundtable for Sustainable Palm Oil (RSPO) standards. RSPO Certification can certainly provide socio-environmental benefits, however there are doubts as to the effectiveness of RSPO, since evidence has shown no significant difference between certified and non-certified plantations for several sustainability metrics (Morgans et al., 2018) and non-certified small holders in Asia have been recognized as more biodiversity-friendly than certified large ones (Azhar et al., 2017). Furthermore mammal and biodiversity conservation depends on larger landscape scales thus certification should either be linked with broader landscape management approaches and/or the landscape itself should be considered as the certified unit (Tscharntke et al., 2015).

In Latin America, 22\% of the palm oil is RSPO certified and growing in numbers, especially in in Brazil, Ecuador, Colombia, Honduras, Guatemala, and Costa Rica [Roundtable on Sustainable Palm Oil (RSPO), 2019]. For example, in Ecuador, the government, civil society and palm oil producers committed to a RSPO Jurisdictional Certification, the first in Latin America. This has the potential to inspire other countries and implement RSPO's principle and criteria at the national level, involving all the stakeholders, large and small, in the production chain [Roundtable on Sustainable Palm Oil (RSPO), 2019]. Initiatives like these, should be coupled with other best practices and standards to increase their effect in wildlife conservation, such as strict adherence to No Deforestation, No Peat, No Exploitation (NDPE) policies by growers, traders and downstream companies, and best practice supervision by NGO's and the public with tools such as ZSL's Sustainability Policy Transparency Toolkit (SPOTT).

\section{EXTINCTION AND MESOPREDATOR RELEASE}

Several mammals are being pushed toward extinction in SE Asia thanks to oil palm's appalling deforestation practices (Clements et al., 2010). The critically endangered Bornean orangutan ( $P$. pygmaeus) have been decimated by up to 100,000 individuals in 16 years by logging, deforestation and industrialized plantations modeling (Voigt et al., 2018). Habitat loss from oil palm is yet another threat to the already dwindling tiger, currently reduced to surviving in protected areas and forest patches (Harihar et al., 2018). To thrive, tigers depend on the existence of large contiguous forest blocks (Sunarto et al., 2012). The future of oil palm practices in SE Asia is thus intimately tied to the survival of these two iconic mammalian species.

For the Neotropical large mammals there is still some time. However, given their size and needs for abundant prey in vast tracts of well-conserved lowland habitats, jaguars are the obvious first mammal species in line of threat from the advancement of oil palm. For this apex carnivore, long term, large enough territories are now in short supply and dwindling (Payán et al., 2012). The species' connectivity currently depends on unprotected lands as a complement to the existing protected areas. Jaguars will use oil palm marginally and cross it, but will not live inside oil palm plantations (Boron et al., 2018). Furthermore, with oil palm come roads, that are actively avoided by females (Conde et al., 2010) and influence jaguar density negatively (Espinosa et al., 2018). The reduction of the jaguar's habitats in the lowland Neotropics will be accelerated by the advancement of oil palm.

Mesopredator release has been recorded inside agricultural lands, and oil palm plantations are no exception. It occurs when large native carnivores are locally extinct and mesopredators thrive in their absence (Crooks and Soulé, 1999). This phenomenon increases pressure on the mesopredator's prey altering their natural abundance and disturbing communities of the preexisting biodiversity (Courchamp et al., 1999). Medium sized carnivores, such as leopard cats (Prionailurus bengalensis) and common civets (Paradoxurus hermaphroditus) use, hunt and are more abundant inside oil palm plantations in Southeast Asian plantations (Rajaratnam et al., 2007; Mohamed et al., 2013; Jennings et al., 2015; Chua et al., 2016). In the Neotropics, 
ocelots, jaguarundis and crab-eating foxes (Cerdocyon thous) are experimenting increased abundances in oil palm plantations (Boron and Payán, 2013; Pardo and Payán, 2015; Pardo et al., 2018a; Boron et al., 2019). The nocturnal and adaptive ocelot (6$12 \mathrm{~kg}$ ) seem to be the counterpart to the nocturnal and highly adaptive leopard cat $(2-7 \mathrm{~kg})$ in Asia, both species which have adapted to eating rodents inside plantations. The impact of mesopredator releases on other biodiversity certainly warrants further research.

\section{CONCLUDING REMARKS}

How new oil palm frontiers are opened and developed will define the extent of alteration of natural mammal assemblages, the intensity of mesopredator release affecting other species from cascading trophic phenomenon and even the continuation of key large iconic herbivores and carnivores. Thus, zoning with planned development, design of plantations respecting forest and water sources, best harvest practices and continued mammal monitoring in small plantations, in a mosaic landscape with natural forest, will be able to retain key mammal species and have a lessened impact on mammal biodiversity on the whole. Stricter certification is needed with verifiable results

\section{REFERENCES}

Ancrenaz, M., Oram, F., Ambu, L., Lackman, I., Ahmad, E., Elahan, H., et al. (2015). Of Pongo, palms and perceptions: a multidisciplinary assessment of Bornean orang-utans Pongo pygmaeus in an oil palm context. Oryx 49, 465-472. doi: 10.1017/S0030605313001270

Azhar, B., Lindenmayer, D. B., Wood, J., Fischer, J., and Zakaria, M. (2014). Ecological impacts of oil palm agriculture on forest mammals in plantation estates and smallholdings. Biodivers. Conserv. 23, 1175-1191. doi: 10.1007/s10531-014-0656-Z

Azhar, B., Saadun, N., Prideaux, M., and Lindenmayer, D. B. (2017). The global palm oil sector must change to save biodiversity and improve food security in the tropics. J. Environ. Manage. 203, 457-466. doi: 10.1016/j.jenvman.2017.08.021

Azhar, B., Saadun, N., Puan, C. L., Kamarudin, N., Aziz, N., Nurhidayu, S., et al. (2015). Promoting landscape heterogeneity to improve the biodiversity benefits of certified palm oil production: evidence from Peninsular Malaysia. Glob. Ecol. Conserv. 3, 553-561. doi: 10.1016/j.gecco.2015. 02.009

Balmford, A., Green, R., and Phalan, B. (2012). What conservationists need to know about farming. Proc. R. Soc. B Biol. Sci. 279, 2714-2724. doi: 10.1098/rspb.2012.0515

Bennie, J. J., Duffy, J. P., Inger, R., and Gaston, K. J. (2014). Biogeography of time partitioning in mammals. Proc. Natl. Acad. Sci. U.S.A. 111, 13727-13732. doi: $10.1073 /$ pnas. 1216063110

Boron, V., Deere, N. J., Xofis, P., Link, A., Quiñones-Guerrero, A., Payán, E., et al. (2019). Richness, diversity, and factors influencing occupancy of mammal communities across human-modified landscapes in Colombia. Biol. Conserv. 232, 108-116. doi: 10.1016/j.biocon.2019.01.030

Boron, V., and Payán, E. (2013). “Abundancia de carnívoros en el agropaisaje de las plantaciones de palma de aceite del valle medio del río Magdalena, Colombia," in Plan de Conservación de Felinos del Caribe Colombiano 2007-2012: Los Felinos y su Papel en la Planificación Regional Integral Basada en Especies Clave, ed C. Castaño-Uribe (Santa Marta: Fundación Herencia Ambiental Caribe, ProCAT Colombia, The Sierra to Sea Institute), 165-176.

Boron, V., Payán, E., MacMillan, D., and Tzanopoulos, J. (2016). Achieving sustainable development in rural areas in Colombia: future scenarios for on wildlife conservation. Application of the abovementioned tactics will consolidate a more sustainable strategy for the future of mammals in oil palm landscapes in mega-diverse countries in the Neotropics. The increase of oil palm cultivation area in Latin America still has the unique opportunity to be done sustainably. We conclude that effectively conserving wild biodiversity in agricultural landscapes will require increased research, policy coordination and application, and strategic support to agricultural communities and conservationists.

\section{AUTHOR CONTRIBUTIONS}

$\mathrm{EP}$ and VB contributed to conception, design of the study, assembled relevant literature, and manuscript revision, read, and approved the submitted version. EP wrote the first draft of the manuscript. VB wrote sections of the manuscript.

\section{ACKNOWLEDGMENTS}

Thank you to the editors for inviting us to submit this perspective. The authors are also grateful to J. Lizarazo, $\mathrm{H}$. Robinson, and our previous coauthors and collaborators in oil palm papers. biodiversity conservation under land use change. Land Use Policy 59, 27-37. doi: 10.1016/j.landusepol.2016.08.017

Boron, V., Xofis, P., Link, A., Payán, E., and Tzanopoulos, J. (2018). Conserving predators across agricultural landscapes in Colombia: habitat use and space partitioning by jaguars, pumas, ocelots and jaguarundis. Oryx doi: 10.1017/S0030605318000327. [Epub ahead of print].

Butler, R. A., and Laurance, W. F. (2009). Is oil palm the next emerging threat to the Amazon? Trop. Conserv. Sci. 2, 1-10. doi: 10.1177/194008290900200102

Cardillo, M., Mace, G. M., Jones, K. E., Bielby, J., Bininda-Emonds, O. R. P., Sechrest, W., et al. (2005). Multiple causes of high extinction risk in large mammal species. Science 309, 1239-1241. doi: 10.1126/science.1116030

Carlson, K. M., Curran, L. M., Asner, G. P., Pittman, A. M., Trigg, S. N., and Marion Adeney, J. (2013). Carbon emissions from forest conversion by Kalimantan oil palm plantations. Nat. Clim. Change 3, 283-287. doi: 10.1038/nclimate1702

Castiblanco, C., Etter, A., and Aide, M. (2013). Oil palm plantations in Colombia: a model of future expansion. Environ. Sci. Policy 27, 172-183. doi: 10.1016/j.envsci.2013.01.003

Chua, M. A. H., Sivasothi, N., and Meier, R. (2016). Population density, spatiotemporal use and diet of the leopard cat (Prionailurus bengalensis) in a human-modified succession forest landscape of Singapore. Mammal Res. 61, 99-108. doi: 10.1007/s13364-015-0259-4

Clements, R., Rayan, D. M., Ahmad Zafir, A. W., Venkataraman, A., Alfred, R., Payne, J., et al. (2010). Trio under threat: can we secure the future of rhinos, elephants and tigers in Malaysia? Biodivers. Conserv. 19, 1115-1136. doi: 10.1007/s10531-009-9775-3

Conde, D. A., Colchero, F., Zarza, H., Christensen, N. L., Sexton, J. O., Manterola, C., et al. (2010). Sex matters: modeling male and female habitat differences for jaguar conservation. Biol. Conserv. 143, 1980-1988. doi: 10.1016/j.biocon.2010.04.049

Courchamp, F., Langlais, M., and Sugihara, G. (1999). Cats protecting birds: modelling the mesopredator release effect. J. Anim. Ecol. 68, 282-292. doi: 10.1046/j.1365-2656.1999.00285.x

Crooks, K. R., and Soulé, M. E. (1999). Mesopredator release and avifaunal extinctions in a fragmented system. Nature 400, 563-566. doi: 10.1038/23028

Diaz-Pulido, A., and Payán, E. (2011). Densidad de ocelotes (Leopardus pardalis) en los llanos colombianos. Mastozoología Neotrop. 18, 63-71. Available online at: https://www.redalyc.org/pdf/457/45719986005.pdf 
Edwards, D. P., Hodgson, J. A., Hamer, K. C., Mitchell, S. L., Ahmad, A. H., Cornell, S. J., et al. (2010). Wildlife-friendly oil palm plantations fail to protect biodiversity effectively. Conserv. Lett. 3, 236-242. doi: 10.1111/j.1755-263X.2010.00107.x

Espinosa, S., Celis, G., and Branch, L. C. (2018). When roads appear jaguars decline: increased access to an Amazonian wilderness area reduces potential for jaguar conservation. PLoS ONE 13:e0189740. doi: 10.1371/journal.pone.0189740

Fitzherbert, E. B., Struebig, M. J., Morel, A., Danielsen, F., Brühl, C. A., Donald, P. F., et al. (2008). How will oil palm expansion affect biodiversity? Trends Ecol. Evol. 23, 538-545. doi: 10.1016/j.tree.2008. 06.012

Furumo, P. R., and Aide, T. M. (2017). Characterizing commercial oil palm expansion in Latin America: land use change and trade. Environ. Res. Lett. 12:024008. doi: 10.1088/1748-9326/aa5892

Garcia-Ulloa, J., Sloan, S., Pacheco, P., Ghazoul, J., and Koh, L. P. (2012). Lowering environmental costs of oil-palm expansion in Colombia. Conserv. Lett. 5, 366-375. doi: 10.1111/j.1755-263X.2012.00254.x

Gibson, L., Lee, T. M., Koh, L. P., Brook, B. W., Gardner, T. A., Barlow, J., et al. (2011). Primary forests are irreplaceable for sustaining tropical biodiversity. Nature 478, 378-381. doi: 10.1038/nature10425

Gilroy, J. J., Prescott, G. W., Cardenas, J. S., Castañeda, P. G., del, P., Sánchez, A., Rojas-Murcia, L. E., et al. (2015). Minimizing the biodiversity impact of Neotropical oil palm development. Glob. Change Biol. 21, 1531-1540. doi: $10.1111 /$ gcb. 12696

Gutiérrez-Vélez, V. H., DeFries, R., Pinedo-Vásquez, M., Uriarte, M., Padoch, C., Baethgen, W., et al. (2011). High-yield oil palm expansion spares land at the expense of forests in the Peruvian Amazon. Environ. Res. Lett. 6:044029. doi: 10.1088/1748-9326/6/4/044029

Harihar, A., Chanchani, P., Borah, J., Crouthers, R. J., Darman, Y., Gray, T. N. E., et al. (2018). Recovery planning towards doubling wild tiger Panthera tigris numbers: Detailing 18 recovery sites from across the range. PLOS ONE 13:e0207114. doi: 10.1371/journal.pone.0207114

Jennings, A. P., Naim, M., Advento, A. D., Aryawan, A. A. K., Ps, S., Caliman, J. P., et al. (2015). Diversity and occupancy of small carnivores within oil palm plantations in central Sumatra, Indonesia. Mammal Res. 60, 181-188. doi: $10.1007 / \mathrm{s} 13364-015-0217-1$

Koh, L. P. (2008). Birds defend oil palms from herbivorous insects. Ecol. Appl. 18, 821-825. doi: 10.1890/07-1650.1

Koh, L. P., Miettinen, J., Liew, S. C., and Ghazoul, J. (2011). Remotely sensed evidence of tropical peatland conversion to oil palm. Proc. Natl. Acad. Sci. U.S.A. 108, 5127-5132. doi: 10.1073/pnas.10187 76108

Koh, L. P., and Wilcove, D. S. (2008). Is oil palm agriculture really destroying tropical biodiversity? Conserv. Lett. 1, 60-64. doi: 10.1111/j.1755-263X.2008.00011.x

Laurance, W. F., Clements, G. R., Sloan, S., O'Connell, C. S., Mueller, N. D., Goosem, M., et al. (2014). A global strategy for road building. Nature 513, 229-232. doi: 10.1038/nature13717

Mohamed, A., Sollmann, R., Bernard, H., Ambu, L. N., Lagan, P., Mannan, S., et al. (2013). Density and habitat use of the leopard cat (Prionailurus bengalensis) in three commercial forest reserves in Sabah, Malaysian Borneo. J. Mammal. 94, 82-89. doi: 10.1644/11-MAMM-A-394.1

Morgans, C. L., Meijaard, E., Santika, T., Law, E., Budiharta, S., Ancrenaz, M., et al. (2018). Evaluating the effectiveness of palm oil certification in delivering multiple sustainability objectives. Environ. Res. Lett. 13:064032. doi: 10.1088/1748-9326/aac6f4

Pardo, L., and Payán, E. (2015). Mamíferos de un agropaisaje de palma de aceite en las sabanas inundables de Orocué (Casanare, Colombia). Biota Colomb. 16, 55-66. Available online at: https://www.redalyc.org/pdf/491/49142418006. pdf
Pardo, L. E., Campbell, M. J., Edwards, W., Clements, G. R., and Laurance, W. F. (2018a). Terrestrial mammal responses to oil palm dominated landscapes in Colombia. PLoS ONE 13:0197539. doi: 10.1371/journal.pone.0197539

Pardo, L. E., de OliveiraRoque, F., Campbell, M. J., Younes, N., Edwards, and Laurance, W. F. (2018b). Identifying critical limits in oil palm cover for the conservation of terrestrial mammals in Colombia. Biol. Conserv. 227, 65-73. doi: 10.1016/j.biocon.2018.08.026

Payán, E., Carbone, C., Homewood, K., Paemelaere, E., Quigley, H., and Durant, S. (2012). "Where will jaguars roam? The importance of survival in unprotected lands," in Molecular Population Genetics, Phylogenetics, Evolutionary Biology and Conservation of the Neotropical Carnivores, eds M. Ruiz-Garcia and J. Shostell (New York, NY: Nova Science), 603-628.

Rajaratnam, R., Sunquist, M., Rajaratnam, L., and Ambu, L. (2007). Diet and habitat selection of the leopard cat (Prionailurus bengalensis borneoensis) in an agricultural landscape in Sabah, Malaysian Borneo. J. Trop. Ecol. 23, 209-217. doi: $10.1017 /$ S0266467406003841

Ripple, W. J., Estes, J. A., Beschta, R. L., Wilmers, C. C., Ritchie, E. G., Hebblewhite, M., et al. (2014). Status and ecological effects of the world's largest carnivores. Science 343:1241484. doi: 10.1126/science. 1241484

Rist, L., Feintrenie, L., and Levang, P. (2010). The livelihood impacts of oil palm: smallholders in Indonesia. Biodivers. Conserv. 19, 1009-1024. doi: 10.1007/s10531-010-9815-z

Roundtable on Sustainable Palm Oil (RSPO) (2019). Available online at: https:// rspo.org/impacts (accessed July 9, 2019).

Sunarto, S., Kelly, M. J., Parakkasi, K., Klenzendorf, S., Septayuda, E., and Kurniawan, H. (2012). Tigers need cover: multi-scale occupancy study of the big cat in sumatran forest and plantation landscapes. PLOS ONE 7:e30859. doi: 10.1371/journal.pone.0030859

Terborgh, J., and Estes, J. A. (2013). Trophic Cascades: Predators, Prey, and the Changing Dynamics of Nature. Washington, DC: Island Press.

Tscharntke, T., Milder, J. C., Schroth, G., Clough, Y., DeClerck, F., Waldron, A., et al. (2015). Conserving biodiversity through certification of tropical agroforestry crops at local and landscape scales. Conserv. Lett. 8, 14-23. doi: $10.1111 /$ conl.12110

Vijay, V., Pimm, S. L., Jenkins, C. N., and Smith, S. J. (2016). The impacts of oil palm on recent deforestation and biodiversity loss. PLoS ONE 11:e0159668. doi: 10.1371/journal.pone. 0159668

Voigt, M., Wich, S. A., Ancrenaz, M., Meijaard, E., Abram, N., Banes, G. L., et al. (2018). Global demand for natural resources eliminated more than 100,000 Bornean Orangutans. Curr. Biol. 28, 761-769.e5. doi: 10.1016/j.cub.2018.01.053

Wassenaar, T., Gerber, P., Verburg, P. H., Rosales, M., Ibrahim, M., and Steinfeld, H. (2007). Projecting land use changes in the Neotropics: The geography of pasture expansion into forest. Glob. Environ. Chang. 17, 86-104. doi: 10.1016/j.gloenvcha.2006.03.007

Wilcove, D. S., Giam, X., Edwards, D. P., Fisher, B., and Koh, L. P. (2013). Navjot's nightmare revisited: logging, agriculture, and biodiversity in Southeast Asia. Trends Ecol. Evol. 28, 531-540. doi: 10.1016/j.tree.2013.04.005

Yue, S., Brodie, J. F., Zipkin, E. F., and Bernard, H. (2015). Oil palm plantations fail to support mammal diversity. Ecol. Appl. 25, 2285-2292. doi: 10.1890/14-1928.1

Conflict of Interest: The authors declare that the research was conducted in the absence of any commercial or financial relationships that could be construed as a potential conflict of interest.

Copyright () 2019 Payán and Boron. This is an open-access article distributed under the terms of the Creative Commons Attribution License (CC BY). The use, distribution or reproduction in other forums is permitted, provided the original author(s) and the copyright owner(s) are credited and that the original publication in this journal is cited, in accordance with accepted academic practice. No use, distribution or reproduction is permitted which does not comply with these terms. 